\title{
New perspective on molecular markers as promising therapeutic targets in germ cell tumors
}

\author{
Paolo Chieffi* \\ Dipartimento di Psicologia, Seconda Università di Napoli, Caserta, Italy.
}

\begin{abstract}
Summary Testicular germ cell tumors (TGCTs) are the most frequent solid malignant tumors in men 20-40 years of age and the most frequent cause of death from solid tumors in this age group. TGCTs comprise two major histologic groups: seminomas and non-seminomas germ cell tumors (NSGCTs). NSGCTs can be further divided into embryonal carcinoma, Teratoma, yolk sac tumor, and choriocarcinoma. Seminomas and NSGCTs present significant differences in clinical features, therapy, and prognosis, and both show characteristics of the Primordial Germ Cells (PGCs). Many discovered biomarkers including HMGA1, GPR30, Aurora-B, estrogen receptor $\beta$, and others have given further advantages to discriminate between histological subgroups and could represent useful therapeutic targets.
\end{abstract}

Keywords: Testicular germ cells tumors, seminomas, Aurora B, GPR30, PATZ1; HMGA

Testicular germ cell tumors (TGCTs) are histologically classified as seminomas and non-seminomas according to the international classification of oncological diseases. Both these tumors display an invasive phenotype and are believed to be derived from a common ancestor, intratubular germ cell neoplasia unclassified (IGCNU) and gonadoblastoma, where the generation and expansion of tumor cells are limited to within the seminiferous tubules (1-4). Non-seminomas, including embryonal carcinoma and teratoma, contain stem cells as well as cells that have differentiated toward somatic lineages to various degrees, thus giving rise to a morphologically pleiotropic appearance (5-9). In contrast, seminomas have a rather uniform appearance, at least at the histological level. Due to this apparently homogenous cell composition, seminomas are particularly suitable for investigations of tumor-associated alterations in gene expression. In addition, the cells that constitute seminomas resemble the primordial germ cells and/ or the cells in the IGCNU. Thus, the gene expression profile in seminomas is interesting not only with regard to understanding their oncogenesis, but it also may be

Released online in J-STAGE as advance publication March 10, 2016.

*Address correspondence to:

Dr. Paolo Chieffi, Dipartimento di Psicologia, Viale Ellittico, 3181100 Caserta, Italy.

E-mail: Paolo.Chieffi@unina2.it useful for research into primordial germ cells (PGCs) (9).

A substantial increase in cure rates of the medical treatment of advanced testicular cancer has raised from approximately $25 \%$ in the mid-1970s to nearly $90 \%$ today. This is the highest cure rate in solid tumor. Improved survival is primarily due to effective chemotherapy (10). A great advance in chemotherapy for TGCT was the introduction of cisplatin in association with vinblastine, and bleomycin. The response rate increased to more than $80 \%$ with the use of this regimen in combination with surgery (10).

The International Germ Cell Cancer Collaborative Group (IGCCCG) was formed and a universal classification scheme was developed. In this stratification system, patients are separated into good-, intermediate-, and poor prognostic groups according to predicted outcome to cisplatin-combination chemotherapy, based on histology, but also on primary site, sites of metastasis, and serum tumor marker elevation $(11,12)$.

Although most patients with testicular cancer will be cured and can expect decades of additional life, thousands of men around the world will still die from testicular cancer every year, and many challenges remain. Cytotoxic chemotherapy remains the mainstay of therapy for advanced disease. A deeper understanding of the molecular mechanisms underlying the development of TGCTs may provide new tools to specifically target neoplastic cells and could contribute to overcome acquired and intrinsic chemotherapy resistance. 
Both clinical and epidemiological evidence strongly suggest that genetic and environmental factors play an important role in the genesis and development of TGCTs. Several genes are implicated in the pathogenesis of TGCTs, but the involvement of other genetic factors remains unknown $(2,3,12,13)$. Susceptibility genes and environmental factors may deregulate normal differentiation processes of PGCs. In fact, TGCT have an invasive phenotype and are believed to be derived from a common ancestor, IGCNU, where the generation and expansion of tumor cells are limited to within the seminiferous tubules $(12,13)$. A number of environmental factors have been investigated to explain the possible links. Some evidence suggests association of increased TGCTs risk and maternal smoking during pregnancy, adult height, body mass index, diet rich in cheese, and others (14). However, the biological mechanisms remain to be elucidated. The incidence of seminomas has been increasing over the last decades. Diagnosis is usually based on identification of histological subgroups. In last years, many potential therapeutic targets has been discovered, including SOX2, SOX17, HMGA1, and HMGA 2, Aurora B, PATZ1, GPR30 and others (1529). Promising molecules capable to selectively target neoplastic cells, that are, serine-threonine kinases, TKs, HMGAs, GPR30 antagonist, proangiogenic factors inhibitors, and micro-RNAs already under clinical evaluation will open a new scenario for TGCTs treatment.

\section{References}

1. Oosterhuis JW, Looijenga LH. Testicular germ-cell tumors in a broader perspective. Nat Rev Cancer. 2005; 5:210-222.

2. Chieffi P, Franco R, Portella G. Molecular and cell biology of testicular germ cell tumors. Int Rev Cell Mol Biol. 2009; 278:277-308.

3. Chieffi P, Chieffi S, Franco R, Sinisi A. Recent advances in the biology of germ cell tumors: Implications for the diagnosis and treatment. J Endocrinol Invest. 2012; 35:1015-1020.

4. Chieffi P, Chieffi S. Molecular biomarkers as potential targets for therapeutic strategies in human testicular germ cell tumours: An overview. J Cell Physiol. 2013; 228:1641-1646.

5. Hanna NH, Einhorn LH. Testicular cancer - Discoveries and Updates. N Engl J Med. 2014; 371:2005-2016.

6. Jones RH, Vasey PA. Part II: Testicular cancer management of advanced disease. Lancet Oncol. 2003; 4:738-747.

7. Skakkebaek NE. Possible carcinoma-in-situ of the testis. Lancet. 1972; 2:2516-2517.

8. Rajpert-De Meyts E, Skakkebaek NE. Pathogenesis of testicular carcinoma in situ and germ cell cancer: Still more questions than answers. Int J Androl. 2011; 34:e2-6.

9. Chieffi P, Chieffi S. An up-date on newly discovered immunohistochemical biomarkers for the diagnosis of human testicular germ cell tumors. Histol Histopathol. 2014; 29:999-1006.
10. Einhorn LH, Donohue J. Cis-diamminedichloroplatinum, vinblastine, and bleomycin combination chemotherapy in disseminated testicular cancer. Ann Intern Med. 1977; 87:293-298.

11. Chieffi P. Molecular targets for the treatment of testicular germ cell tumors. Mini Rev Med Chem. 2007; 7:755-759.

12. Chieffi P. Recent advances in molecular and cell biology of testicular germ cell tumors. Int Rev Cell Mol. 2014; 312,79-100.

13. Chieffi P. Molecular targets for the treatment of testicular germ cell tumors. Mini Rev Med Chem. 2007; 7:755-759.

14. Lutke Holzik MF, Rapley EA, Hoekstra HJ, Sleijfer DT, Nolte IM, Sijmons RH. Genetic predisposition to testicular germ-cell tumours. Lancet Oncol. 2004; 5:363371.

15. Chieffi P, Battista S, Barchi M, Di Agostino S, Pierantoni G, Fedele M, Chiariotti L, Tramontano D, Fusco A. HMGA 1 and HMGA2 protein expression in mouse spermatogenesis. Oncogene. 2002; 21:3644-3650.

16. Franco R, Esposito F, Fedele M, Liguori G, Pierantoni G, Botti G, Tramontano D, Fusco A, Chieffi P. Detection of high mobility group proteins $\mathrm{A} 1$ and $\mathrm{A} 2$ represents a valid diagnostic marker in post-puberal testicular germ cell tumours. J Pathol. 2008; 214:58-64.

17. Pero R, Lembo F, Di Vizio D, Boccia A, Chieffi P, Fedele M, Pierantoni MG, Rossi P, Iuliano R, Santoro M, Viglietto G, Bruni CB, Fusco A, Chiariotti L. RNF4 is a growth inhibitor expressed in germ cells and lost in human testicular tumours. Am J Pathol. 2001; 159:12251230.

18. Pero R, Lembo F, Chieffi P, Del Pozzo G, Fedele M, Fusco A, Bruni CB, Chiariotti L. Translational regulation of a novel testis-specific RNF4 transcript. Mol Reprod Dev. 2003; 66:1-7.

19. Fedele M, Franco R, Salvatore G, Paronetto MP, Barbagallo F, Pero R, Chiariotti L, Sette C, Tramontano D, Chieffi G, Fusco A, Chieffi P. PATZ1 gene has a critical role in the spermatogenesis and testicular tumours. J Pathol. 2008; 215:39-47.

20. Esposito F, Boscia F, Franco R, Tornincasa M, Fusco A, Kitazawa S, Looijenga LH, Chieffi P. Down-regulation of estrogen receptor- $\beta$ associates with transcriptional coregulator PATZ1 delocalization in human testicular seminomas. J Pathol. 2011; 224:110-120.

21. Esposito F, Boscia F, Gigantino V, Tornincasa M, Fusco A, Franco R, Chieffi P. The high mobility group A1oestrogen receptor $\beta$ nuclear interaction is impaired in human testicular seminomas. J Cell Physiol. 2012; 227:3749-3755

22. Barbagallo F, Paronetto MP, Franco R, Chieffi P, Dolci S, Fry AM, Geremia R, Sette C. Increased expression and nuclear localization of the centrosomal kinase Nek2 in human testicular seminomas. J Pathol. 2009; 217:431441.

23. Vicini E, Loiarro M, Di Agostino S, Corallini S, Capolunghi F, Carsetti R, Chieffi P, Geremia R, Stefanini M, Sette C. 17- $\beta$-estradiol elicits genomic and nongenomic responses in mouse male germ cells. J Cell Physiol. 2006; 206:238-245.

24. Franco R, Boscia F, Gigantino V, Marra L, Esposito F, Ferrara D, Pariante P, Botti G, Caraglia M, Minucci $\mathrm{S}$, Chieffi P.GPR30 is over-expressed in post puberal testicular germ cell tumors. Cancer Biol Ther. 2011; 11:609-613.

25. Boscia F, Passaro C, Gigantino V, Perdonà S, Franco R, 
Portella G, Chieffi S, Chieffi P. High levels of GPR30 protein in human testicular carcinoma in situ and seminomas correlate with low levels of estrogen receptorbeta and indicate a switch in estrogen responsiveness. J Cell Physiol. 2015; 230:1290-1297.

26. Chieffi P, Troncone G, Caleo A, Libertini S, Linardopoulos S, Tramontano D, Portella G. Aurora B expression in normal testis and seminomas. J Endocrinol. 2004; 181:263-270.

27. Esposito F, Libertini S, Franco R, Abagnale A, Marra L, Portella G, Chieffi P. Aurora B expression in post-puberal testicular germ cell tumours. J Cell Physiol. 2009; 221:435-439.

28. Portella G, Passaro C, Chieffi P. Aurora B: A new prognostic marker and therapeutic target in cancer. Curr Med Chem. 2011; 18:482-496.

29. Chieffi P, Boscia F. New discovered molecular markers as promising therapeutic targets in germ cell tumors. Exp Opin Orphan Drugs. 2015; 3:1021-1030.

(Received February 12, 2016; Accepted February 26, 2016) 